Disclosure of Interests: Philip J Mease Grant/research support from: AbbVie, Amgen, BMS, Celgene, Janssen, Lilly, Novartis, Pfizer, SUN and UCB, Consultant for: AbbVie, Amgen, BMS, Galapagos, Gilead Sciences, Inc., Janssen, Lilly, Novartis, Pfizer, SUN and UCB, Speakers bureau: AbbVie, Amgen, BMS, Celgene, Genentech, Janssen, Lilly, Novartis, Pfizer and UCB, Mei Liu Employee of: M. Liu is an employee of Corrona, LLC., Sabrina Rebello Employee of: Corrona, LLC, Robert McLean: None declared, Blessing Dube Employee of: B. Dube is an employee of Corrona, LLC., Meghan Glynn Employee of: M. Glynn is an employee of Corrona, LLC., Esther Yi Consultant for: E. Yi is a postdoctoral fellow at the University of Texas at Austin and Baylor Scott and White Health, providing services to Novartis Pharmaceuticals Corporation., Yujin Park Employee of: Y. Park is an employee of Novartis., Alexis Ogdie Grant/ research support from: (To my university) Novartis, Pfizer, Grant/research support from: Novartis, Pfizer, Grant/research support from: Novartis, Pfizer, Grant/research support from: Novartis, Pfizer, Consultant for: AbbVie, Bristol-Myers Squibb, Celgene, Corrona, Eli Lilly and Company, Novartis, Pfizer, and Takeda, Consultant for: AbbVie, Amgen, BristolMyers Squibb, Celgene, Corrona, Eli Lilly, Novartis, Pfizer Inc, Takeda, Consultant for: Abbvie, Amgen, BMS, Celgene, Corrona, Lilly, Novartis, Pfizer, Takeda, Consultant for: Abbvie, Amgen, BMS, Celgene, Corrona, Lilly, Novartis, Pfizer, Takeda

DOI: 10.1136/annrheumdis-2019-eular.1154

\section{SAT0307 LONG-TERM ASSOCIATION BETWEEN DISEASE ACTIVITY MEASURED BY ASDAS AND PHYSICAL FUNCTION IN A LARGE EARLY AXIAL SPONDYLOARTHRITIS COHORT}

Pedro Carvalho ${ }^{1}$, Ana Marreiros ${ }^{2}$, Adeline Ruyssen-Witrand ${ }^{3}$, Pedro Machado ${ }^{4}$. ${ }^{1}$ Centro Hospitalar do Algarve - Hospital de Faro, Faro, Portugal; ${ }^{2}$ Algarve Biomedical Center, Faro, Portugal; ${ }^{3}$ Le centre Hospitalier Universitaire de Toulouse, Toulouse, France; ${ }^{4}$ University College London, London, United Kingdom

Background: The Ankylosing Spondylitis Disease Activity Score (ASDAS) has been progressively replacing the Bath Ankylosing Spondylitis Disease Activity Score (BASDAI) as the main disease activity measure to assess patients with axial spondyloarthritis (axSpA), both in the research context as well as in clinical practice. However, further evidence is needed to show its meaningfulness regarding the longitudinal relationship with physical function.

Objectives: To study the long-term association between disease activity and physical function in axSpA.

Methods: DESIR is a prospective observational cohort of patients with recent onset ( $<3$ years) inflammatory back pain, suggestive of axSpA. We analysed data collected during the first five years of follow-up and selected patients with a definite diagnosis of axSpA according to the treating rheumatologist. Physical function was assessed using the Ankylosing Spondylitis Health Assessment Questionnaire (HAQ-AS). Disease activity was measured using the ASDAS C-reactive protein (ASDAS-CRP) and BASDAI. In a first step, associations between HAQ-AS (dependent variable) and disease activity (defined by ASDAS or BASDAI), clinical and demographic variables were tested in univariable models. Multivariable models were then built adjusting for potential confounding factors found to be significant in the univariable analysis.

In a second step, additional multivariable analysis was conducted using the Chi-square Automatic Interaction Detector (CHAID) method, with HAQAS as dependent variable. The following independent variables were tested: ASDAS/BASDAI, enthesitis score, arthritis, employment status, gender, symptom duration, body mass index (BMI), HLA-B27 status, treatment with non-steroidal anti-inflammatory drugs (NSAID), conventional disease modifying anti-rheumatic drugs (CDMARD) and TNF-blockers. The final model fixed as criteria: 70 parent nodes and 20 child nodes to create new generations in the decision tree.

Results: Data from 644 patients and 4944 visits were analysed. There was a significant independent association between HAQ-AS and gender, employment status, peripheral arthritis, ASDAS-CRP/BASDAI, enthesitis, NSAID and anti-TNF treatment (Table 1). The decision tree revealed ASDAS as the first variable with discriminative power on HAQ-AS, according to the following cut points: 1.3, 2.2 and 2.4. In addition, for ASDAS values above 3.5 the model yield a higher number of explanatory variables setting different patients' profiles regarding their functional status, namely: gender, anti-TNF and NSAID treatment. Notably, the ASDAS cut-offs that separated different patient profiles largely mim icked the cut-offs previously defined for ASDAS disease activity states (inactive, low, high and very high disease activity). According to this hierarchical model, gender, anti-TNF treatment and enthesitis score were the next variables explaining $\mathrm{HAQ}-\mathrm{AS}$ variation, followed by employment status and NSAID treatment.

Conclusion: We have shown that disease activity contributes longitudinally to physical function and that it is hierarchically superior to any other variables or disease domains. Previously defined ASDAS-CRP disease activity categories identified different patient profiles on the hierarchical analysis.

\section{REFERENCE}

None.

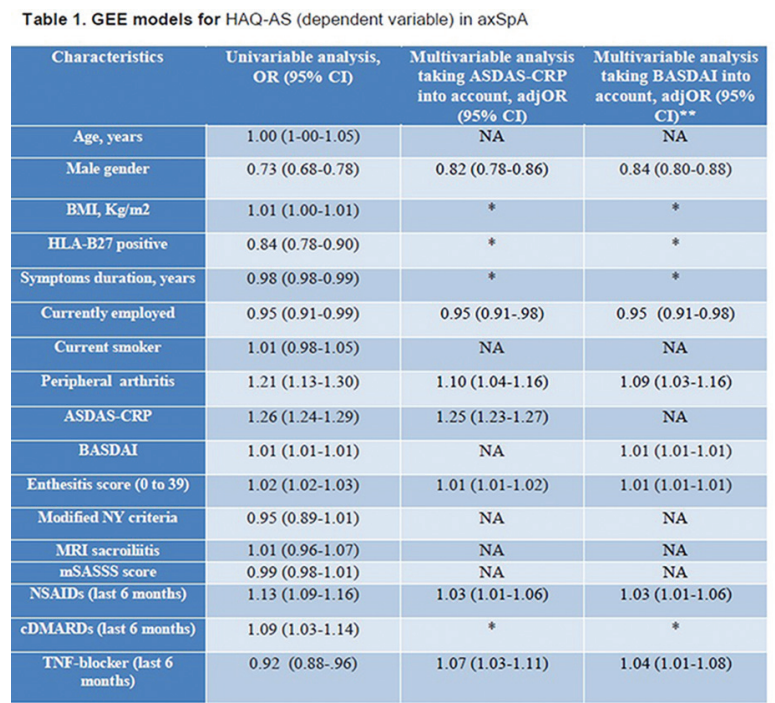

"Not selected for this model; NA - not applicable; "* Model adjusted with the cofactors considered significant in the proposed multivariable model for ASDAS (previous column)

Disclosure of Interests: Pedro Carvalho: None declared, Ana Marreiros: None declared, Adeline Ruyssen-Witrand: None declared, Pedro Machado Consultant for: Abbvie, BMS, Celgene, Janssen, MSD, Novartis, Pfizer Roche and UCB, Speakers bureau: Abbvie, BMS, Celgene, Janssen, MSD, Novartis, Pfizer, Roche and UCB

DOI: 10.1136/annrheumdis-2019-eular.1831

\section{SAT0308 CLUSTER-BASED SPONDYLOARTHRITIS PHENOTYPES DEFINED AT BASELINE ARE PREDICTIVE OF 5-YEAR SEVERITY OUTCOME IN THE DESIR COHORT}

Felicie Costantino $^{1,2}$, Philippe Aegerter ${ }^{3}$, Anna Moltó $^{4,5}$, Maxime Breban ${ }^{1,2}$, MariaAntonietta D'agostino ${ }^{1,2} .^{1}$ INSERM/Versailles-Saint Quentin University, UMR1173, Versailles-Saint Quentin, France; ${ }^{2}$ Ambroise Paré Hospital (AP-HP), Department of Rheumatology, Boulogne-Billancourt, France; ${ }^{3}$ GIRCI IdF-INSERM VersaillesSaint Quentin University, Public Health Department, Versailles-Saint Quentin, France; ${ }^{4}$ Hôpital Cochin (AP-HP), Paris Descartes University Department of Rheumatology, Paris, France; ${ }^{5}$ INSERM CRESS, U1153, Paris, France

Background: The course of axial spondyloarthritis (SpA) is heterogeneous, varying from mild to severe and remains to be better defined. DESIR is a French cohort of early undifferentiated axial SpA that are longitudinally followed-up, offering such opportunity. We recently performed a cluster analysis in the DESIR cohort, according to baseline characteristics and identified 2 clusters: one characterized by an isolated axial disorder (A for axial) and one by additional high frequency of peripheral 